\title{
Confirmation of linkage of Sjögren-Larsson syndrome to chromosome 17 in families of different ethnic origins
}

Department of

Dermatology,

Great Ormond Street

Hospital for Children,

Great Ormond Street,

London WC1N 3JH,

UK

M Lacour

J I Harper

Unit of Clinical

Genetics and Fetal

Medicine,

Institute of Child

Health,

London, UK

H R Middleton-Price

Correspondence to:

Dr Lacour.

Received 7 August 1995

Revised version accepted for

publication 25 October 1995

\author{
Marc Lacour, Helen R Middleton-Price, John I Harper
}

remained the question of whether this disease is genetically heterogeneous. This report confirms the linkage in non-Swedish pedigrees and, therefore, provides evidence to support a single locus for SLS. (f Med Genet 1996;33:258-259)

Key words: Sjögren-Larsson syndrome; chromosome 17; linkage analysis.

Sjögren-Larsson syndrome (SLS) (MIM 270200) is a rare, autosomal recessive, neurocutaneous disorder characterised by the association of congenital ichthyosis, spastic di- or quadriplegia, and mental retardation. ${ }^{1}$ Patients present at birth with generalised skin thickening and brown, fine scaling which is particularly pronounced around the umbilicus, the neck, and flexures. Glistening white dots in the fundus of the eye are sometimes present. Mental retardation is severe in most patients, who usually become confined to a wheelchair during later childhood owing to progressive spasticity.

SLS is caused by a deficiency in the fatty aldehyde dehydrogenase component of a complex enzyme, the fatty alcohol NAD + oxidoreductase (FAO). ${ }^{23}$ The disorder has a worldwide distribution, although most of the published cases are from the northern part of Sweden. Most of the Swedish patients can be traced to a specific region in Sweden, known as the SLS area, where a mutation was introduced in around the 13th century. ${ }^{45}$ Using linkage analysis in 24 families from this area, Pigg et $a l^{6}$ recently found that the SLS gene is located on chromosome 17 flanked by D17S805 and D17S783.

In order to confirm linkage of Sjögren-Larsson syndrome to the same region in non-Swedish pedigrees, blood for DNA was taken from a large consanguineous Pakistani pedigree with affected first cousins, a further consanguineous pedigree of English origin, and a small Indian family. At least one affected subject in each family was previously reported to have deficient FAO activity in cultured fibroblasts, leucocytes, and skin. ${ }^{7}$ To analyse microsatellite polymorphisms PCR was performed in $25 \mu$ l using 250 ng DNA, 25 pmol either D17S805 or D17S783 5'-digoxigenin labelled primers, and $1 \mathrm{U}$ of Taq polymerase in $1 \times \mathrm{KCl}$ buffer. PCR cycles were as follows: 10 minutes at $94^{\circ} \mathrm{C}$, $30 \times$ (one minute at $60^{\circ} \mathrm{C}(\mathrm{D} 17 \mathrm{~S} 805)$ or $65^{\circ} \mathrm{C}$ (D17S783), 30 seconds at $72^{\circ} \mathrm{C}, 30$ seconds at $\left.94^{\circ} \mathrm{C}\right), 10$ minutes at $72^{\circ} \mathrm{C}$. A total of $3 \mu \mathrm{l}$ 
Two point lod scores between SLS and D17S783 and D17S805

\begin{tabular}{lllllll}
\hline & 0 & & & \\
& 0.00 & 0.01 & 0.10 & 0.20 & 0.30 & 0.40 \\
\hline SLS-D17S783 & 2.85 & 2.77 & 2.01 & 1.20 & 0.57 & 0.20 \\
SLS-D17S805 & 2.29 & 2.24 & 1.74 & 1.22 & 0.74 & 0.32 \\
\hline
\end{tabular}

of the PCR products were run on a $6 \%$ sequencing gel and blotted for one hour on a nylon membrane (Hybond-N +, Amersham). Alleles were then detected with a DIG luminescent Kit (Boehringer Mannheim).

The alleles found in SLS families for microsatellite markers at D17S783 and D17S805 were sized by comparing those of CEPH reference subject 1347-02. Linkage analysis was carried out using the MLINK and LINKMAP sections of the LINKAGE program package. The distance between D17S783 and S17S805 was fixed at $2 \mathrm{cM}$. The gene frequency was set at $0 \cdot 0005$. Allele frequencies for the markers were as published by Genethon.

The results are shown in the figure. Two point lod scores are shown in the table. Multipoint linkage analysis gave a maximum multipoint lod score of $5 \cdot 25$ at D17S783 and 5.19 at D17S805. Pedigree 1 gave a significant maximum multipoint lod score of 3.53 at D17S783.
The gene for SLS was mapped to proximal $17 \mathrm{q}$ in 24 Swedish families but the possibility of genetic heterogeneity could not be ruled out since these data were produced in a distinct population where affected subjects are thought to originate from a common ancestor. We have provided evidence which shows linkage of SLS to chromosome 17 in pedigrees from different ethnic groups which, therefore, supports the localisation and the hypothesis of a single locus for SLS. This information will allow carrier detection and prenatal diagnosis and will be useful in the counselling of families with SLS.

The authors thank Sally Cottrell and Karen Heath for their generous assistance. M Lacour was supported by a grant from La Fondation Eugenio Litta, Vaduz, Liechtenstein.

1 Sjögren $\mathrm{T}$, Larsson $\mathrm{T}$. Oligophrenia in combination with congenital ichthyosis and spastic disorders. Acta Psychiatr congenital ichthyosis and

2 Rizzo W, Dammann A, Craft D, et al. Sjögren-Larsson syndrome: inherited defect in the fatty alcohol cycle. $\mathcal{F}$ Pediatr 1989;115:228-34

3 Rizzo W, Craft D. Sjögren-Larsson syndrome. Deficient activity of the fatty aldehyde dehydrogenase component of fatty alcohol: NAD + oxidoreductase in cultured fibroblasts. F Clin Invest 1991;88:1643-8.

4 Jagell S, Gustavson KH, Holmgren G. Sjögren-Larsson syndrome in Sweden A clinical genetic and epidemiological study. Clin Genet 1981;19:233-56.

5 Iselius L, Jagell S. Sjögren-Larsson syndrome in Sweden: distribution of the gene. Clin Genet 1989;35:272-5.

6 Pigg M, Jagell S, Sillén A, et al. The Sjögren-Larsson syndrome gene is close to D17S805 as determined by linkage analysis and allelic association. Nature Genet 1994;8:361-4.

7 Judge M, Lake B, Smith V, Besley G, Harper J. Depletion of alcohol (hexanol) dehydrogenase activity in the epidermis and jejunal mucosa in Sjögren-Larsson syndrome. F Invest Dermatol 1990;95:632-4. 